(ISSN - 2752-7018)

VOLUME 02 ISSUE 01 Pages: 106-109

SJIF IMPACT FACTOR (2021: 5. 376)

OCLC - 1276789625 METADATA IF - 7.569
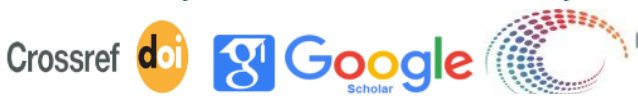

metดpดTa indexing 5, WorldCat" for MENDELEY

Publisher: Frontline Journals

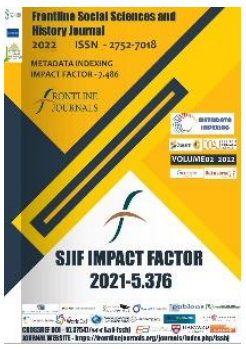

Journal Website: https://frontlinejournal s.org/journals/index.ph $\mathrm{p} /$ fsshj

Copyright: Original content from this work may be used under the terms of the creative commons attributes 4.0 licence.
Research Article

\section{NOVERBAL MEANS OF UZBEK AND ENGLISH SPEAKING ETHICS}

Submission Date: January 11, 2022, Accepted Date: January 20, 2022,

Published Date: January 31, 2022

Crossref doi: https://doi.org/10.37547/social-fsshj-02-01-14

Munavvar A'zamjon qizi Usmonova

Second year Master's student, Fergana State University, Uzbekistan

\title{
Abstract
}

The article describes the ideas of speech etiquette, methods of its use, factors of nonverbal communication. As long as the culture of communication is based on knowledge and enlightenment, moral education, good knowledge of the heritage of our ancestors and devotion to our spiritual values, there is no doubt that it is an important sign of cultural and enlightenment development of society.

\section{KeYWORDS}

Etiquette, gestures, speech, nonverbal communication, communication, culture.

\section{INTRODUCTION}

Therefore, it is not difficult to understand this from the first days of our independence, when the focus was on spiritual and educational issues, education and upbringing. All the reforms in this 
(ISSN - 2752-7018)

VOLUME 02 ISSUE 01 Pages: 106-109

SJIF IMPACT FACTOR (2021: 5 · 376)

OCLC - 1276789625 METADATA IF - 7.569

area are based on the love and affection for our young people, who are the future of our country, the future of our people, more precisely, for a mentally and physically healthy, harmoniously developed generation. The laws of the Republic "On the State Language", "On Education", "National Training Program" and many other documents pay special attention to the above issues. We all need to understand that the concepts of communication and interaction have a socio-political significance today. In the current complex and dangerous period of growing ideological, ideological and information struggles in the international arena, the organization of spiritual and educational work in accordance with modern requirements, protection of our youth from various ideological attacks, the formation of a conscious attitude to life, The task is to increase the sense of involvement in the events, to consistently fight against aggression that could threaten the independence of our country, our peaceful life, to review and improve the work in this area, to debate "with enlightenment against ignorance." requires the training of rhetoricians and talented speakers who can communicate and communicate.

\section{THE MAIN PART}

Some gestures have come a long way in human development, and not only have they lost their original meaning in the course of evolution, but they have even changed them. For example, an undoubtedly friendly gesture, such as a smile, originally had the exact opposite meaning (meaning a threat) in our primitive past. Clearly, gestures are informative; it is not only national but also social and can be formed during a particular activity. Gestures, facial expressions, gestures, glances - in short, the whole range of nonverbal ways of transmitting information, serves as a means of transmitting information to the outside world. This, of course, proves once again that nonverbal means are related to the human factor.In some cultures, the context is so important that in some cases the meaning of what is said can be reversed. That's why nonverbal communication is so important. In business conversations, for example, Uzbeks are closer to each other than Americans. In other words, Uzbeks have less social distance than Americans, and their personal or personal distances do not match. Such a reduction in social distance can be interpreted by Americans as a violation of morality. Prolonged distance is seen as a formality in Uzbek-Uzbek relations. After a few encounters, this misconception usually 
disappears. But first, this situation can lead to tension in the conversation. From the above, it can be said that people of different nationalities prefer the following distances when speaking:

Close distance - Arabs, Japanese, South Americans, French, Greeks, blacks and Spaniards, Italians, Spaniards living in North America;

Average distance - English, Swedish, Swiss, German, Austrian;

Long distance - North Americans are white, Australians, New Zealanders.

The use of gestures and symbols is one of the most common misunderstandings. Such gestures are often used when they do not know the language spoken by the interlocutor, but some try to explain themselves by believing that the gestures have the same meaning everywhere. This, in turn, leads to deep misunderstandings, ridicule, and sometimes embarrassment.

Therefore, if you do not know the exact meaning of the gestures, it is better to exclude them completely when communicating with foreigners. This is because the gestures may not be understood by the other person or may have a different meaning.
However, there is no denying that there are nonverbal behaviours that are common to many cultures. At the same time, people in different countries are developing their own rules for building their own nonverbal behaviour. Each of these rules can be individual.

For example, if we raise our hand and shake it, depending on the situation, this gesture can be both a farewell and a greeting. In some cases, it may even mean "no." Or shaking your head can mean both denial and hesitation. This suggests that nonverbal means are also homonymous.

Of course, all peoples have almost the same gestures, expressive signals (smiles, angry looks, frowning, shaking your head, etc.). However, there are many non-verbal means and customs that are accepted only by one nation. For example, in formal meetings, they usually shake hands when an agreement is reached.

In general, a person uses five different sign systems in communication: words, intonation, tone of voice, gestures, and energy impulses. The first three belong to the field of traditional linguistics, the fourth to nonverbal communication, and the fifth to extralinguistics. 


\section{Conclusion}

The following conclusions were drawn from the study of the pragmatic features of nonverbal means of speech:

Through speech, a person receives certain information in society, and at the same time transmits certain information through speech. It is in this process that nonverbal means emerge to increase the effectiveness of speech. In turn, nonverbal means are the main aids in the expression of language signs in speech. Exactly nonverbal means are considered to be one of the key factors in generating a pragmatic process in the speech process.

\section{REFERENCES}

1. Hakimov, M. Fundamentals of Uzbek pragmalinguistics. Tashkent. 2013.

2. Muminov S., Rasulov K. 2007. "On the social role of communicants and verbal communication". Current Problems of Methodology and Phraseology, 70-72. Samarkand: SamSU.
3. Raximov, S. Rechevaya kommunikatsiya i problema deyksisa $\mathrm{v}$ razno-sistemnyx yazykax. Tashkent: Fan. 2008.

4. Rasuljanovna, I. N. (2020). The verbal lacunas in chinese and uzbeklanguages (on the example of grammatical and somatic lacunas). ACADEMICIA: An International Multidisciplinary Research Journal, 10(5), 196-1700.

5. Ismatullaeva, N. R. (2020). Methods of Elimination Of Lexical Gaps In Translation (on example of Chinese and Uzbek languages). Scientific Bulletin of Namangan State University, 2(10), 305-314. 